\title{
Evaluation of Strawberry Species and Cultivars for Powdery Mildew Resistance in Open-field and High Tunnel Production Systems
}

\author{
Colleen Kennedy, Tomas N. Hasing, Natalia A. Peres, \\ and Vance M. Whitaker ${ }^{1}$ \\ Gulf Coast Research and Education Center, University of Florida, 14625 CR \\ 672, Wimauma, FL 33598
}

Additional index words. disease resistance, Podosphaera aphanis, Fragaria chiloensis, Fragaria virginiana

\begin{abstract}
Many breeders have turned to wild relatives in search of beneficial traits such as disease resistance. In strawberry, the wild octoploid species Fragaria virginiana and $F$. chiloensis are fully interfertile with the cultivated species, $F$. $\times$ ananassa, and are therefore potential sources of resistance. Powdery mildew may increase in economic importance in Florida in the near future as a result of the use of high tunnels and rowcovers for freeze protection, which limit free water and provide a favorable environment for disease development. The objective of this study was to screen an elite group of wild strawberry accessions for resistance to powdery mildew under two production systems. In 2010-11 and 2012-13, wild accessions, commercial standard cultivars, and susceptible controls were planted in open-field and high tunnel environments at the Gulf Coast Research and Education Center in Balm, FL. Although there was a significant year $x$ genotype effect, some taxa showed high levels of resistance that were consistent across years. There was a high correlation for ratings of powdery mildew between the high tunnel and the open field for all genotypes $(r=0.89, P<0.001)$. This information may be useful for breeders, because sources of resistance to powdery mildew are available within the tested genotypes. However, some accessions are highly susceptible to powdery mildew, and this must be considered when using these genotypes in breeding programs.
\end{abstract}

Powdery mildew is a major fungal disease of strawberry that has been observed in all parts of the world where strawberries are grown (Peries, 1962a) that thrives in open fields and high tunnels (Demchak, 2009; Maas, 1998; Xiao et al., 2001). The causal agent of powdery mildew in strawberry is the obligate, biotrophic fungus, Podosphaera aphanis (Wallr.) U. Braun and S. Takam. [formerly Sphaerotheca macularis (Wall. ex Fries) Jacz f. sp. fragariae (Peries)].

The signs and symptoms of powdery mildew include white, powdery-looking mycelial growth, usually on the lower surface of the leaves, upward curling of the leaf edges, dry and purplish patches on the lower leaf surface, and dark round structures (cleistothecia) embedded in the mycelia. Severely infected plants have reduced vigor (Daubeny, 1961). Powdery mildew of strawberry infects all aboveground organs including leaves, stolons, flowers, and fruits (Peres and Mertely, 2009). When powdery mildew infects flowers, fruit may become malformed or aborted (Peres and Mertely, 2009). Late-season infection of ripening fruits can cause substantial crop loss (Horn et al., 1972).

Received for publication 6 June 2013. Accepted for publication 3 July 2013.

${ }^{1}$ To whom reprint requests should be addressed; e-mailvwhitaker@ufl.edu.
Conidia of $P$. aphanis are primarily spread by wind (Blanco et al., 2004; Strand, 2008), and dispersal is inhibited by free water (Blanco et al., 2004; Peries, 1962a; Strand, 2008) such as rain or overhead irrigation. Conidia germinate at temperatures between 15 and $25^{\circ} \mathrm{C}$ (Amsalem et al., 2006; Peries, 1962 a) when relative humidity is above $75 \%$ (Jhooty and Mckeen, 1965). With optimal conditions, conidia on strawberry leaves germinate 4 to $6 \mathrm{~h}$ after inoculation and form appressoria (Belanger and Labbe, 2002) within $12 \mathrm{~h}$ (Jhooty and Mckeen, 1965). Germination and colony development are adversely affected by free water (Peries, 1962a).

Control of powdery mildew in annual systems relies on the use of disease-free transplants and applications of foliar sprays of protectant or systemic fungicides (Maas, 1998). Elemental sulfur, which is probably the oldest protectant fungicide (Agrios, 1997), can be applied at the first sign of disease but may cause plant injury when applied at temperatures above $26{ }^{\circ} \mathrm{C}$ (Amsalem et al., 2006; Peries, 1962a). Systemic, broad-spectrum fungicides such as myclobutanil and triflumizole have limited curative actions and are applied at lower rates. However, as a result of the relative ease with which powdery mildews develop resistance to systemic fungicides (Hollomon and Wheeler, 2002), it is recommended that these compounds be rotated to lessen the chance for development of resistance (Hollomon and Wheeler, 2002; Peres and Mertely, 2009). Commercial cultivars of strawberry have varying levels of resistance to powdery mildew (Nelson et al., 1996). The most widely grown cultivar in Florida over the last decade, 'Strawberry Festival' (Chandler et al., 2000) (internationally known as 'Florida Festival'), is characterized as susceptible to this disease (Peres and Mertely, 2009).

Florida is the major fresh strawberry supplier to the eastern states and Canada from December through March with over 4000 ha in production with a crop value of \$366 million in 2010-11 (NASS, 2010). In Florida, strawberries are grown as an annual crop in a plasticulture system. Bare-root transplants are established in October and fruit harvest begins in late November. In the main Florida strawberry-growing region, there are usually several nights with frost each season and overhead irrigation is used to protect plants from freeze damage. In 2000, producers in Hillsborough and Manatee counties withdrew $61,000 \mathrm{~kL} \cdot \mathrm{d}^{-1}$ of water from the underlying aquifer for production and protection of strawberry (U.S. Geological Survey, 2012). The use of water for freeze protection may become challenging as a result of increasing water restrictions in these counties.

Protective systems such as high tunnels and rowcovers are beginning to provide an alternative means to protect Florida strawberries from freeze damage. These cultural systems are becoming more popular worldwide for season extension/optimization as well as for frost protection (Hancock and Simpson, 1995; Ogden and van Iersel, 2009; Salame-Donoso et al., 2010). However, as a result of the lack of free water in these production systems, conditions are favorable for development of powdery mildew (Xiao et al., 2001). Therefore, powdery mildew may have an increased economic impact in the near future in Florida.

In most modern agricultural crops, breeders have turned to wild relatives as a source of beneficial traits such as disease resistance (Hajjar and Hodgkin, 2007). Hancock et al. (2001) assembled a group of native Fragaria chiloensis from North and South America and F. virginiana from North America, which are held at the National Clonal Germplasm Repository in Corvallis, OR. On introduction to the "supercore," accessions were noted for desirable characteristics by their original collectors. Several were noted as being powdery mildew-resistant/tolerant including North American F. chiloensis accessions Redwood Creek Park-37 (PI 551445) and Brandon State Park-14 (PI 551459) and North American $F$. virginiana accessions JP 95-9-6 (PI 612320), NC 95-21-1 (PI 612569), NC 96-35-2 (PI 612323), NC 96-48-1 (PI 612324), NC 96-5-3 (PI 612325), NC 95-19-1 (PI 612486), Eagle 14 (PI 612492), Fredrick 9 (PI 612493), and Montreal River 10 (PI 612497) (Hancock et al., 2001). However, these field observations have yet to be confirmed through replicated studies. $F$. virginiana accessions collected from 
areas with relatively dry summer climates such as Alaska, Alberta, and parts of the Pacific Northwest were noted as the most susceptible to powdery mildew (Hancock and Luby, 1993).

In strawberry, the wild octoploid species $F$. virginiana and $F$. chiloensis are fully interfertile with the cultivated species $F$. $\times$ ananassa. It is believed that the cultivated strawberry resulted from an accidental hybridization of these two wild species in Europe $\approx 250$ years ago (Hancock and Luby, 1993). Attempts have been made to reconstruct this important cross from newly collected clones of $F$. virginiana and $F$. chiloensis (Hancock et al., 2010; Luby et al., 2008; Stegmeir et al., 2010). Others have used $F$. virginiana crossed with $F$. Xananassa for incorporating remontant flowering (Bringhurst, 1976; Dale et al., 2002; Hancock et al., 2002), and $F$. chiloensis was used to improve the fruit size of California germplasm (Bringhurst and Voth, 1984).

For wild germplasm to be usefully characterized for powdery mildew resistance for a breeding program, the material should be evaluated in the environment where it will be used as a result of the inherent variability of natural inoculum sources. Climatic conditions during the winter months in Florida are ideal for the development of powdery mildew on strawberry as a result of extended periods of cool temperatures and high humidity, providing an excellent opportunity to screen germplasm.

The objective of this study was to screen an elite group of wild strawberry accessions (Hancock et al., 2001) and important cultivars for resistance to powdery mildew under field and high tunnel production systems in Florida. These data may be useful to strawberry breeders who are seeking to introgress wild species germplasm into their breeding populations.

\section{Materials and Methods}

Plant material and data collection. Experiments were performed at the University of Florida Gulf Coast Research and Education Center (GCREC) at Balm, FL, during the 2010-11 and 2012-13 seasons. Twentyseven accessions of the Fragaria supercore collection were obtained from the National Clonal Germplasm Repository in Corvallis, OR. The accessions were propagated from runner tips, which were rooted under intermittent mist in a greenhouse at the GCREC. Rooted tips were transplanted into soilless media (Fafard 2 Mix; Fafard, Agawam, MA) in 3.8-L pots to make mother plants for further propagation. Mother plants of three University of Florida cultivars, 'Florida Elyana', 'Florida Radiance' (internationally known as 'Florida Fortuna'), and 'Strawberry Festival' (internationally known as 'Florida Festival'), and two susceptible controls (breeding lines FL 11-17 and FL 09-17) were also maintained in $3.8-\mathrm{L}$ pots on the same greenhouse benches for propagation. After 3 months, runner tips were collected from mother plants for all genotypes on 7 Sept.
2010 and 17 Sept. 2012 and rooted under intermittent mist in plug trays (Landmark Plastic Corporation, Akron, OH). In 2010 11,60 -cell trays were used and in 2012-13 40 -cell trays were used. In both years, the plug transplants were grown for $\approx 6$ weeks in a common greenhouse environment before planting in the field. According to standard practice in the breeding program, powdery mildew in the greenhouse was chemically controlled as needed and per label recommendations on both the mother plants and the plug plants with Torino (active ingedient cyflufenamid) (Gowan Company, Yuma, AZ), Quintec (active ingedient quinoxyfen) (Dow Chemical, Midland, MI), Quadris (active ingedient azoxystrobin) (Syngenta, Greensboro, NC), and Microthiol (active ingedient sulfur) (United Phosphorus, King of Prussia, PA).

Raised beds in the field were formed 4 to 6 weeks before planting and were $71 \mathrm{~cm}$ wide at the base, $61 \mathrm{~cm}$ wide on the top, and $25 \mathrm{~cm}$ high. Beds were fumigated with a mixture of telone (1,3D-dichloropropene) and chloropicrin according to current commercial standards and covered in black high-density polyethylene mulch. Two rows of planting holes were punched with $38-\mathrm{cm}$ in-row spacing. The wild accessions along with cultivar and susceptible standards were planted in both open-field and high tunnel production environments and were arranged in a randomized complete block design within each environment with raised beds serving as blocks. Four replications of five-plant plots were planted on 22 Oct. 2010 and on 25 Oct. 2012. After establishment, plants were irrigated through the drip tape twice per day with one irrigation between $0800 \mathrm{HR}$ and $0900 \mathrm{HR}$ and another between 1300 HR and 1400 HR with durations of between $30 \mathrm{~min}$ and $60 \mathrm{~min}$ depending on time of year, age of the plants, and water availability. Fertigation was applied through drip tape beginning $10 \mathrm{~d}$ after transplanting. Fertilization and pest control followed current crop recommendations for strawberry in Florida (Santos et al., 2011); however, no products were applied to control powdery mildew.

The susceptible standard in the 2010-11 trial (FL 09-17) was identified from a seedling subset of the 2009-10 UF breeding population (unpublished data). The susceptible standard for the 2012-13 trial (FL 11-17) was developed through a divergent selection breeding scheme from parents selected from the same population as the 2010-11 standard (unpublished data). The standards were chosen to represent the most susceptible extreme of the main breeding population in each year. The trial relied on naturally occurring inoculum, and ratings for powdery mildew were initiated when the abaxial leaf surfaces of the susceptible standards were nearly $100 \%$ covered with mycelium. Ratings for the 2010-11 trial were taken on 24 Feb. and 25 Feb. 2011 for the high tunnel and openfield plots, respectively. The 2012-13 trial ratings were taken on 3 Jan. 2013. The percent coverage of powdery mildew mycelium on the abaxial surface of fully expanded trifoliate leaves was subjectively rated using a modified Horsfall-Barratt scale of 0 to 6 where $0=0 \%$ to $1 \%$ coverage, $1=1 \%$ to $10 \%, 2=10 \%$ to $25 \%, 3=25 \%$ to $50 \%, 4=$ $50 \%$ to $75 \%, 5=75 \%$ to $95 \%$, and $6=95 \%$ to $100 \%$ coverage (Horsfall and Barratt, 1945). Every plant within a plot was inspected by gently turning and laying over the entire bulk of stems and leaves to expose the abaxial surfaces of the leaves. Fully expanded trifoliate leaves were examined, and a score was assigned on a plot mean basis. Weather data were collected from Florida Automated Weather Network (Florida Automated Weather Network, 2013).

Statistical analysis. Data were analyzed by genotype (accession) and also by taxon, similar to Pinkerton and Finn (2005). Taxa were grouped according to the species and subspecies designations listed in the Germplasm Resources Information Network (USDA, ARS, National Genetic Resources Program, 2013). As a result of the ordinal nature of the response variable (HorsfallBarratt scale), data were analyzed by means of generalized linear mixed models with a cumulative logit link function and a multinomial probability distribution. The effect of the blocks was modeled as random normal, whereas the effect of species, year, location, and their interactions were set as fixed. The goodness of fit of the model showed a better fit compared with a generalized linear model (which assumes normality of the response) using the Akaike Information Criterion. Odds ratios were calculated to compare means of the genotypes or taxon groups with the means of the susceptible controls. The statistical analysis was performed using the GLIMMIX procedure of $\mathrm{SAS}^{\circledR}$ software (Version 9.3; SAS Institute Inc., Cary, NC) with the maximum likelihood estimation based on Laplace's method. Additionally, a Pearson correlation coefficient was estimated on genotype mean ratings (combined across years) between the high tunnel and the open-field environments.

\section{Results and Discussion}

The analysis revealed significant differences among genotypes for resistance to powdery mildew as evidenced by a highly significant effect of genotype in the model (Table 1). There were also significant differences among taxon groups (Table 2). The effect of production environment and its interactions were not significant (Tables 1 and 2), and there was a high and significant Pearson correlation coefficient for genotype means (across years) between the high tunnel and the open field $(r=0.89, P<0.001)$. Both the genotype and taxon analyses revealed a significant year $\times$ genotype effect (Tables 1 and 2); therefore, genotype and taxon means are presented across production environments and within year (Tables 3 and 4).

Mean disease scores for the wild species accessions, cultivars, and susceptible standards ranged from 0.00 to 5.88 , from 0.00 to 
Table 1. Type III tests of fixed effects of genotype, year, and production environment (high tunnel and open field) on the powdery mildew ratings of fully expanded leaves of wild and cultivated strawberry accessions in Balm, FL, in 2010-11 and 2012-13.

\begin{tabular}{lcccr}
\hline Effect & Numerator df & Denominator df & F Value & Pr $>$ F \\
\hline Genotype (G) & 31 & 354 & 4.67 & $<0.0001$ \\
Year (Y) & 1 & 12 & 0.00 & 0.9982 \\
Environment (E) & 1 & 12 & 0.00 & 0.9881 \\
Y $\times$ G & 29 & 354 & 2.04 & 0.0015 \\
G $\times$ E & 31 & 354 & 1.01 & 0.4529 \\
Y $\times$ E & 1 & 12 & 0.00 & 0.9948 \\
Y $\times$ E $\times$ G & 29 & 354 & 0.84 & 0.7136 \\
\hline
\end{tabular}

Table 2. Type III tests of fixed effects of taxon, year, and production environment (high tunnel and open field) on powdery mildew ratings of fully expanded leaves of wild and cultivated strawberry accessions in Balm, FL, in 2010-11 and 2012-13.

\begin{tabular}{lcccc}
\hline Effect & Numerator df & Denominator df & F Value & Pr $>$ F \\
\hline Taxon (T) & 11 & 430 & 10.83 & $<0.0001$ \\
Year (Y) & 1 & 12 & 0.00 & 0.998 \\
Environment (E) & 1 & 12 & 0.00 & 0.9949 \\
Y $\times$ T & 11 & 430 & 2.92 & 0.001 \\
T $\times$ E & 11 & 430 & 1.19 & 0.2908 \\
$\mathrm{Y} \times \mathrm{E}$ & 1 & 12 & 0.00 & 0.9994 \\
$\mathrm{Y} \times \mathrm{E} \times \mathrm{G}$ & 10 & 430 & 1.06 & 0.3951 \\
\hline
\end{tabular}

Table 3. Means and SEMs (0-6 scale) of strawberry genotypes evaluated in Balm, FL, during the 2010-11 and 2012-13 seasons sorted by overall mean (not shown). ${ }^{\mathrm{z}}$

\begin{tabular}{|c|c|c|c|c|c|c|}
\hline \multirow[b]{2}{*}{ Genotype $^{y}$} & \multirow[b]{2}{*}{ Taxon code } & \multirow[b]{2}{*}{ PI no. } & \multicolumn{2}{|c|}{$2010-11$} & \multicolumn{2}{|c|}{$2012-13$} \\
\hline & & & Mean & SE & Mean & $\overline{\mathrm{SE}}$ \\
\hline JP 95-9-6 & FVGY $^{x}$ & 612320 & $0.00^{*}$ & 0.00 & $0.00^{*}$ & $\overline{0.00}$ \\
\hline NC 96-48-1 & FVVS & 612324 & $0.00 *$ & 0.00 & $0.00^{*}$ & 0.00 \\
\hline Eagle 14 & FVVN & 612492 & $0.00^{*}$ & 0.00 & $0.00^{*}$ & 0.00 \\
\hline Fredrick 9 & FVVN & 612493 & $0.00^{*}$ & 0.00 & $0.00^{*}$ & 0.00 \\
\hline LH 50-4 & FVVN & 612495 & $0.00^{*}$ & 0.00 & $0.00 *$ & 0.00 \\
\hline RH 23 & FVVN & 612498 & $0.00 *$ & 0.00 & $0.00^{*}$ & 0.00 \\
\hline RH 30 & FVVN & 612499 & $0.00 *$ & 0.00 & $0.00 *$ & 0.00 \\
\hline NC 95-21-1 & FVGY & 612569 & $0.00 *$ & 0.00 & $0.00^{*}$ & 0.00 \\
\hline JP 95-1-1 & FVGY & 612570 & $0.00 *$ & 0.00 & $0.00 *$ & 0.00 \\
\hline BC Canada & FCP & 612488 & $0.13^{*}$ & 0.13 & $0.13^{*}$ & 0.13 \\
\hline Montreal River 10 & FVVN & 612497 & $0.38 *$ & 0.38 & $0.00^{*}$ & 0.00 \\
\hline Darrow 72 & FCPC & 236579 & $0.38^{*}$ & 0.18 & $0.25^{*}$ & 0.16 \\
\hline NC 96-35-2 & FVVS & 612323 & $0.63 *$ & 0.26 & $0.38 *$ & 0.26 \\
\hline Festival & FA & & $0.38 *$ & 0.18 & $0.88^{*}$ & 0.13 \\
\hline Radiance & FA & & $0.00 *$ & 0.00 & $1.88^{*}$ & 0.13 \\
\hline Pacific Crest Trail 110 & FVC & 551527 & $1.63^{*}$ & 0.50 & $0.38^{*}$ & 0.18 \\
\hline WLSP-08 & FCL & 551453 & $2.00 *$ & 0.87 & $0.13^{*}$ & 0.13 \\
\hline Elyana & FA & & $1.14^{*}$ & 0.55 & $1.38^{*}$ & 0.26 \\
\hline CA 1367 & FCL & 551728 & $2.13^{*}$ & 0.30 & $0.50 *$ & 0.19 \\
\hline RCP 37 & FCL & 551445 & 4.38 & 0.63 & $1.13^{*}$ & 0.30 \\
\hline FL 09-17 & FA & & 4.13 & 0.44 & - & - \\
\hline NC 96-5-3 & FVVS & 612325 & 3.88 & 0.67 & $2.63^{*}$ & 0.56 \\
\hline La Tapera & FCPC & 612317 & 5.00 & 0.33 & $3.63^{*}$ & 0.38 \\
\hline Black Hills S. Dak. & FVG & 612494 & 5.13 & 0.48 & $3.63^{*}$ & 0.46 \\
\hline LH 30-4 & FVG & 612501 & 4.38 & 0.63 & $4.38^{*}$ & 0.26 \\
\hline Ice H59 & FVP & 551471 & 4.38 & 0.86 & $4.63^{*}$ & 0.53 \\
\hline Scotts Creek & FCP & 612490 & $5.50 *$ & 0.38 & $3.63^{*}$ & 0.46 \\
\hline March Brava & FCPC & 612316 & 4.63 & 0.53 & 5.50 & 0.19 \\
\hline Termas de Chillan & FCPC & 552091 & 5.38 & 0.38 & 5.25 & 0.41 \\
\hline NAH 3 & $\mathrm{FCC}$ & 612318 & $5.75^{*}$ & 0.16 & $5.00^{*}$ & 0.27 \\
\hline FL 11-17 & FA & & - & - & 5.63 & 0.18 \\
\hline Rio Palena & FCPC & 602568 & 5.00 & 0.68 & 5.88 & 0.13 \\
\hline
\end{tabular}

${ }^{\mathrm{z}}$ Genotype means denoted by an asterisk are significantly different from the susceptible control (bold font) at $P \leq 0.05$ based on odds ratios and their confidence intervals.

${ }^{y}$ Sources of plant material; plants with a PI number are sourced from the National Clonal Germplasm Repository, Corvallis, OR; cultivars and controls are maintained at Gulf Coast Research and Education Center, Balm FL.

${ }^{\mathrm{x}}$ For explanation of taxon codes, see Table 4.

1.88 , and from 4.13 to 5.63 , respectively (Table 3). In 2010-11, all genotypes were significantly different from the susceptible control except RCP 37 (PI 551445), NC 96-5-3 (PI 612325), La Tapera (PI 612317), Black
Hills S. Dak. (PI 612494), LH 30-4 (PI 612501), Ice H59 (PI 551471), March Brava (PI 612316), Termas de Chillan (PI 552091), and Rio Palena (PI 602568) (Table 3). In 2012-13, only March Brava (PI 612316),
Termas de Chillan (PI 552091), and Rio Palena (PI 602568) were not different from the susceptible control (Table 3).

For the analysis of taxon groups, all were different from the susceptible control except $F$. chiloensis subsp. $f$. chiloensis, $F$. chiloensis $f$. patagonica subsp. chiloensis, and $F$. virginiana subsps. glauca and platypetala. The most resistant taxa were $F$. virginiana subsp. grayana and $F$. vigininia subs. virginiana (North) (Table 4). F. virginiana subsp. grayana was represented by three genotypes including two, NC 95-21-1 (PI 612569) and JP 95-9-6 (PI 612320), which were previously noted as resistant (Hancock et al., 2001), as well as JP 95-1-1 (PI 612570). These three accessions were collected from the southern U.S. in Mississippi, GA, and Florida (Hancock et al., 2001). F. vigininia subs. virginiana (North) was composed of six genotypes including Ontario genotypes previously reported as resistant, Eagle 14 (PI 612492), Fredrick 9 (PI 612493), and Montreal River 10 (PI 612497) (Hancock et al., 2001) (Table 3). The three other accessions belonging to this taxon group were $\mathrm{RH} 23$ and RH 30 (PI 612498 and PI 612499, respectively) from Minnesota and LH 50-4 (PI 612495) collected in Montana. All genotypes within these taxa showed high levels of resistance that were consistent across years. Given the large geographic range spanned by these resistant accessions, with widely differing climactic conditions, it is likely that multiple mechanisms of resistance are represented. However, the present study did not involve a finer scale examination of such mechanisms.

Within $F$. chiloensis, no particular subspecies showed clear and consistent resistance (Table 4). However, F. chiloensis subsp. lucida, which includes accessions collected in Washington and California, had mean ratings of 2.83 in $2010-11$ and 0.58 in 2012-13 (Table 4). Individual accessions that could be considered as sources of resistance are BC Canada (PI 612488) and Darrow 72 (PI 236579) ( $F$. chiloensis $f$. patagonica subsp. chiloensis). Darrow 72, from Chile, is a standout among the $f$. patagonica subsp. chiloensis, because the other four genotypes within this group, also from Chile, La Tapera (PI 612317), March Brava (PI 612316), Termas de Chillan (PI 552091), and Rio Palena (PI 602568) had high disease scores (Table 3). Redwoods Creek Park 37 (RCP 37; PI 551445), previously noted as resistant (Hancock et al., 2001), had a mean rating of 4.38 in 2010-11 and 1.13 in 2012-13 (Table 3).

In contrast to the results of this study, several previous articles have reported a higher incidence of powdery mildew in protected environments than in the open field (Darrow et al., 1954; Xiao et al., 2001). However, Gooding et al. (1981) found a high correlation $(r=0.92 ; P=0.001)$ between disease scores for strawberry powdery mildew in a tunnel and an open field in Scotland, which is consistent with the present study. In California, Nelson et al. (1995) reported genetic correlations for incidence and severity of 
Table 4. Means and SEMs ( $0-6$ scale) of strawberry taxon groups evaluated in Balm, FL. during the 2010-11 and $2012-13$ seasons sorted by overall mean (not shown). ${ }^{\mathrm{z}}$

\begin{tabular}{|c|c|c|c|c|c|c|}
\hline \multirow[b]{2}{*}{ Species } & \multirow[b]{2}{*}{ Taxon code } & \multirow{2}{*}{$\begin{array}{c}\text { No. of } \\
\text { genotypes }\end{array}$} & \multicolumn{2}{|c|}{$2010-11$} & \multicolumn{2}{|c|}{$2012-13$} \\
\hline & & & Mean & $\mathrm{SE}$ & $\overline{M e a n}$ & $\mathrm{SE}$ \\
\hline F. virginiana subsp. grayana & FVGY & 3 & $0.00^{*}$ & 0.00 & $0.00^{*}$ & $\overline{0.00}$ \\
\hline F. virginiana subsp. virginiana (North) & FVVN & 6 & $0.06 *$ & 0.06 & $0.00 *$ & 0.00 \\
\hline F. ×ananassa (cultivars) & FA & 3 & $0.48^{*}$ & 0.21 & $1.38^{*}$ & 0.13 \\
\hline F. cascadensis & $\mathrm{FVC}$ & 1 & $1.63 *$ & 0.50 & $0.38 *$ & 0.18 \\
\hline F. virginiana subsp. virginiana (South) & FVVS & 3 & $1.50^{*}$ & 0.42 & $1.00 *$ & 0.31 \\
\hline F. chiloensis subsp. lucida & FCL & 3 & $2.83 *$ & 0.42 & $0.58^{*}$ & 0.15 \\
\hline F. chiloensis subsp. pacifica & FCP & 2 & $2.81 *$ & 0.72 & $1.88^{*}$ & 0.51 \\
\hline F. chiloensis f. patagonica subsp. chiloensis & FCPC & 5 & 4.08 & 0.36 & 4.10 & 0.35 \\
\hline F. $\times$ ananassa (susceptible control) & FL 09-17 & 1 & 4.13 & 0.44 & - & 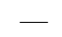 \\
\hline F. virginiana subsp. glauca & FVG & 2 & 4.75 & 0.39 & 4.00 & 0.27 \\
\hline F. virginiana subsp. platypetala & FVP & 1 & 4.38 & 0.86 & 4.63 & 0.53 \\
\hline F. chiloensis subsp. f. chiloensis & FCC & 1 & 5.75 & 0.16 & 5.00 & 0.27 \\
\hline F. $\times$ ananassa (susceptible control) & FL 11-17 & 1 & - & - & 5.63 & 0.18 \\
\hline
\end{tabular}

${ }^{\mathrm{z}}$ Taxon means denoted by an asterisk are significantly different from the susceptible control (bold font) at $P \leq 0.05$ based on odds ratios and their confidence intervals.

powdery mildew in greenhouse- vs. fieldgrown breeding selections where infection levels were either low or high. When field infection levels were high, correlations between disease severity in the field vs. incidence and severity in the greenhouse were reported as highly significant $(r=0.97 ; P=$ $0.01)$. However, when field infection levels were low, correlations were lower and were non-significant in some cases. Further research by the same authors revealed that under uniformly high disease pressure, the genotypic (total genetic) correlation of severity ratings between greenhouse-grown seedlings and plants in the field was high $(r=0.84 ; P=$ 0.01) (Nelson et al., 1996). The authors suggested that different genes confer resistance when the plant is challenged with different levels of disease pressure.

A highly significant genotype $\times$ year interaction raises the possibility of variable expression of resistance mechanisms and/or morphological characteristics for some of the genotypes across years. Because the study relied on naturally occurring inoculum, pathogenic variability across years cannot be ruled out as a second possible cause of the significant interaction. During the first 6 weeks of the study, the average temperatures were nearly $5^{\circ}$ lower in 2012 than in 2010 . During the next 4 weeks, temperatures in 2012 were more than $12^{\circ}$ higher than in 2010 (Florida Automated Weather Network, 2013). These variable conditions may have caused differences in the rate of development of the strawberry transplants. Mechanisms of resistance in strawberry against powdery mildew have not been well elucidated. However, some morphological factors have been identified that influence disease development, namely leaf age and leaf surface characteristics. The rate of conidial germination is higher on younger leaves than on older leaves (Amsalem et al., 2006; Asalf et al., 2010), and severity of powdery mildew can be significantly higher on young folded or partially unfolded leaves than on completely expanded and fully mature leaves (Carisse and Bouchard, 2010).

Sombardier et al. (2009) reported a greater propensity for powdery mildew infection on the abaxial verses adaxial surface of leaves. The authors suggest this may be the result of stomatal openings on the abaxial surface and a thick cuticle on the adaxial surface. Although only the abaxial surface was rated for powdery mildew in the current study, powdery mildew was observed on the adaxial surface of some of the most susceptible accessions. Peries (1962b) is in agreement that strawberry leaf resistance to powdery mildew is correlated to the relative difficulty of haustoria penetration of the cuticle and outer epidermal wall; however, this author suggests that surface waxes may provide a stimulating effect on penetration and that cutin acids may function as inhibitors to penetration. Morphologically, F. chiloensis accessions typically have thick, leathery leaves, which are in great contrast to the leaves of $F$. virginiana, which are noticeably less waxy and robust. One might conclude that the morphology of $F$. chiloensis leaves could contribute to greater powdery mildew resistance. However, in this study, the delicate leaves of several $F$. virginiana accessions were completely free of mycelia, whereas the most susceptible accessions included $F$. chiloensis from South America.

\section{Conclusions}

Many breeders have turned to wild relatives as a source of beneficial traits. Using an accession of $F$. virginiana subsp. glauca collected from southern Colorado, powdery mildew resistance was introgressed into a small subpopulation of the University of Florida breeding material. Using three backcross generations, fruit size and commercially desirable plant architecture were partially recovered while maintaining resistance (unpublished data). Clearly, there are sources of powdery mildew resistance among elite accessions of the available wild germplasm that have exhibited greater resistance than commercial cultivars. However, many wild accessions appear to be much more susceptible than current cultivars and should be used with caution. Should a breeder decide to use the most susceptible wild genotypes to access other important traits, there is risk of introducing powdery mildew susceptibility into the breeding population.

\section{Literature Cited}

Agrios, G.N. 1997. Plant pathology. 5th Ed. Elsevier Academic Press, Burlington, MA.

Amsalem, L., S. Freeman, D. Rav-David, Y. Nitzani, A. Sztejnberg, I. Pertot, and Y. Elad. 2006. Effect of climatic factors on powdery mildew caused by Sphaerotheca macularis f. sp. fragariae on strawberry. Eur. J. Plant Pathol. 114:283-292.

Asalf, B., A. Stensvand, D.M. Gadoury, R.C. Seem, and A. Tronsmo. 2010. Effect of leaf age on primary infection and development of colonies of strawberry powdery mildew. Phytopathology 100:S8.

Belanger, R.R. and C. Labbe. 2002. Control of powdery mildews without chemicals: Prophylacitc and biological alternatives for horticultural crops, p. 256-267. In: Belanger, R.R., W.R. Bushnell, A.J. Dik, and T.L.W. Carver (eds.). The powdery mildews: A comprehensive treatise. APS Press, St. Paul, MN.

Blanco, C., B. de los Santos, C. Barrau, F.T. Arroyo, M. Porras, and F. Romero. 2004. Relationship among concentrations of Sphaerotheca macularis conidia in the air, environmental conditions, and the incidence of powdery mildew in strawberry. Plant Dis. 88:878-881.

Bringhurst, R.S. 1976. Day-neutral vs. short-day strawberry breeding advantages and exploitation potential. Fruit Var. J. 30:25.

Bringhurst, R.S. and V. Voth. 1984. Breeding octoploid strawberries. Iowa State J. Res. 58: 371-381.

Carisse, O. and J. Bouchard. 2010. Age-related susceptibility of strawberry leaves and berries to infection by Podosphaera aphanis. Crop Prot. 29:969-978.

Chandler, C.K., D.E. Legard, D.D. Dunigan, T.E. Crocker, and C.A. Sims. 2000. 'Strawberry Festival' strawberry. HortScience 35:13661367.

Dale, A., J.J. Luby, and J.F. Hancock. 2002. Breeding dayneutral strawberries for northern North America. Acta Hort. 567:133-136.

Darrow, G.M., D.H. Scott, and A.C. Goheen. 1954. Relative resistance of strawberry varieties to powdery mildew at Beltsville, Maryland, 1954. Plant Dis. Rptr. 38:864-866.

Daubeny, H.A. 1961. Powdery mildew resistance in strawberry progenies. Can. J. Plant Sci. 41: 239-243.

Demchak, K. 2009. Small fruit production in high tunnels. HortTechnology 19:44-49.

Florida Automated Weather Network. 2013. University of Florida, Gainesville, FL. 1 May 2013. $<$ http://fawn.ifas.ufl.edu/ $>$.

Gooding, H.J., R.J. McNicol, and D. MacIntyre. 1981. Methods of screening strawberries for resistance to Sphaerotheca macularis (Wall ex Frier) and Phytophthora cactorum (Leb. and Cohn). J. Hort. Sci. 56:239-245.

Hajjar, R. and T. Hodgkin. 2007. The use of wild relatives in crop improvement: A survey of developments over the last 20 years. Euphytica 156:1-13.

Hancock, J. and D. Simpson. 1995. Methods of extending the strawberry season in Europe. HortTechnology 5:286-290.

Hancock, J.F., P.W. Callow, A. Dale, J.J. Luby, C.E. Finn, S.C. Hokanson, and K.E. Hummer. 2001. From the Andes to the Rockies: Native strawberry collection and utilization. HortScience 36:221-225.

Hancock, J.F., C.E. Finn, J.J. Luby, A. Dale, P.W. Callow, and S. Serce. 2010. Reconstruction of 
the strawberry, Fragaria ×ananassa, using genotypes of $F$. virginiana and $F$. chiloensis. HortScience 45:1006-1013.

Hancock, J.F. and J.J. Luby. 1993. Genetic-resources at our doorstep-The wild strawberries. Bioscience 43:141-147.

Hancock, J.F., J.J. Luby, A. Dale, P.W. Callow, S. Serce, and A. El-Shiek. 2002. Utilizing wild Fragaria virginiana in strawberry cultivar development: Inheritance of photoperiod sensitivity, fruit size, gender, female fertility and disease resistance. Euphytica 126:177-184.

Hollomon, D.W. and I.E. Wheeler. 2002. Controlling powdery mildews with chemistry. p. 249255. In: Belanger, R.R. W.R. Bushnell, A.J. Dik, and T.L.W. Carver (eds.). The powdery mildews: A comprehensive treatise. APS Press, St. Paul, MN.

Horn, N.L., K.R. Burnside, and R.B. Carver. 1972. Powdery mildew of strawberry. Plant Dis. Rptr. 4:368.

Horsfall, J.G. and R.W. Barratt. 1945. An improved grading system for measuring plant diseases. Phytopathology 35:655.

Jhooty, J.S. and W.E. Mckeen. 1965. Studies on powdery mildew of strawberry caused by Sphaerotheca macularis. Phytopathology 55: 281-285.

Luby, J.J., J.F. Hancock, A. Dale, and S. Serce. 2008. Reconstructing Fragaria $\times$ ananassa utilizing wild $F$. virginiana and $F$. chiloensis: Inheritance of winter injury, photoperiod sensitivity, fruit size, female fertility and disease resistance in hybrid progenies. Euphytica 163:57-65.

Maas, J.L. 1998. Compendium of strawberry diseases. 2nd Ed. APS Press, St. Paul, MN.
NASS. 2010. Quick Stats. U.S. Department of Agriculture, Washington, DC. 12 Apr. 2012. $<$ http://quickstats.nass.usda.gov/>.

Nelson, M.D., W.D. Gubler, and D.V. Shaw. 1995. Inheritance of powdery mildew resistance in greenhouse-grown versus field-grown California strawberry progenies. Phytopathology 85 : 421-424.

Nelson, M.D., W.D. Gubler, and D.V. Shaw. 1996. Relative resistance of 47 strawberry cultivars to powdery mildew in California greenhouse and field environments. Plant Dis. 80:326-328.

Ogden, A.B. and M.W. van Iersel. 2009. Southern highbush blueberry production in high tunnels: Temperatures, development, yield, and fruit quality during the establishment years. HortScience 44:1850-1856.

Peres, N.A. and J.C. Mertely. 2009. Powdery mildew of strawberries. Plant Pathology Department, Florida Cooperative Extension Service, Institute of Food and Agricultural Sciences, University of Florida, Gainesville, FL. 12 Apr. 2012. <http://edis.ifas.ufl.edu/ pp129>.

Peries, O.S. 1962a. Studies on strawberry mildew, caused by Sphaerotheca macularis (Wallr. Ex Fries) Jaczewski. 1. Biology of fungus. Ann. Appl. Biol. 50:211-224.

Peries, O.S. 1962b. Studies on strawberry mildew, caused by Sphaerotheca macularis (Wallr. Ex Fries) Jaczewski. 2. Host-parasite relationships on foliage of strawberry varieties. Ann. Appl. Biol. 50:225-233.

Pinkerton, J. and C.E. Finn. 2005. Responses of strawberry species and cultivars to the rootlesion and northern root-knot nematodes. HortScience 40:33-38.
Salame-Donoso, T.P., B.M. Santos, C.K. Chandler, and S.A. Sargent. 2010. Effects of high tunnels on strawberry growth, yield, and postharvest quality in Florida. HortScience 45:503.

Santos, B.M., N.A. Peres, J.F. Price, V.M. Whitaker, P.J. Dittmar, S.M. Olson, and S.A. Smith. 2011. Strawberry production in Florida. UF/IFAS, Gainesville, FL. 9 Aug. 2012. <http://edis. ifas.ufl.edu/pdffiles/cv/cv13400.pdf $>$.

Sombardier, A., S. Savary, D. Blancard, J. Jolivet, and L. Willocquet. 2009. Effects of leaf surface and temperature on monocyclic processes in Podosphaera aphanis, causing powdery mildew of strawberry. Can. J. Plant Pathol. 31: 439-448.

Stegmeir, T.L., C.E. Finn, R.M. Warner, and J.F. Hancock. 2010. Performance of an elite strawberry population derived from wild germplasm of Fragaria chiloensis and $F$. virginiana. HortScience 45:1140-1145.

Strand, L.L. 2008. Integrated pest management for strawberries. 2nd Ed. The Regents of the University of California, Oakland, CA.

USDA, ARS, National Genetic Resources Program. 13 Apr. 2013. Germplasm Resources Information Network (GRIN) [online database]. USDA, ARS, National Germplasm Resources Laboratory, Beltsville, MD. 3 July 2013. <http://www. ars-grin.gov/cgi-bin/npgs/html/index.pl>.

U.S. Geological Survey, Reston, VA. 12 Apr. 2012. <http://www.usgs.gov>.

Xiao, C.L., C.K. Chandler, J.F. Price, J.R. Duval, J.C. Mertely, and D.E. Legard. 2001. Comparison of epidemics of Botrytis fruit rot and powdery mildew of strawberry in large plastic tunnel and field production systems. Plant Dis. 85:901-909. 